\title{
Analisis Beban Kerja Dengan Metode Workload Analysis (WLA) Dalam Menentukan Jumlah Tenaga Kerja Optimal Di PT INDOJT
}

\author{
Hermanto $^{* 1}$, Widiyarini² \\ ${ }^{1,2}$, Program Study Teknik industri, FTIK, Universitas Indraprasta PGRI/ \\ Program Pascasarjana Doktor Ilmu Ekonomi Universitas Borobudur Jakarta. \\ Jl. Nangka No.58c / TB Simatupang, Jagakarsa, Tanjung Barat, Jakarta Selatan 12350 \\ Email: hers3sm@gmail.com¹, Widya2513@gmail.com².
}

DOI: 10.20961/performa.19.2.46467

\section{Abstrak}

Sumber daya manusia merupakan salah satu unsur penting dalam pelaksanaan suatu proyek karena pengaruhnya yang cukup besar terhadap biaya dan waktu. Beban kerja yang ditanggung oleh tenaga kerja sangat berkaitan erat dengan efesiensi dan efektifitas pada suatu proyek. Banyak cara yang dapat dilakukan dalam efesiensi sumber daya manusia, antara lain adalah dengan lebih mengoptimalkan jumlah tenaga kerja. PT Jaya Teknik Indonesia, sebagai salah satu perusahaan yang bergerak dibidang kontrakor Mekanika, Elektrikal, Elektronik dan Teknologi Informasi. juga tidak lepas dari permasalahan beban kerja ini, pekerjaan yang merangkap dengan pekerjaan yang lain merupakan salah satu penyebabnya. Dengan menggunakan metode Workload Analysis (WLA) untuk menentukan beban kerja. Dari hasil analisis metode WLA didapatkan beban kerja Quality control Tower 1 sebesar 119\%, Supervisor Tower 2 sebesar 135\% dan Supervisor Tower 3 sebesar 124\% disamping itu, setelah dilakukan perhitungan didapatkan jumlah karyawan yang optimal dengan penambahan sebanyak 1 tenaga kerja pada Tower 1, Tower 2 dan Tower 3.

Kata kunci: Analisis Beban Kerja, Workload Analysis, Pengukuran Kerja

\begin{abstract}
Human resources is one of the important elements in the implementation of a project because of its considerable influence on costs and time. The workload borne by the workforce is closely related to the efficiency and effectiveness of a project. There are many ways that can be done in the efficiency of human resources, among others, by optimizing the number of workers. PT Jaya Teknik Indonesia, as one of the companies engaged in the contractor of Mechanics, Electrical, Electronics and Information Technology. also can not be separated from the problem of this workload, work that doubles with other jobs is one of the causes. By using the Workload Analysis (WLA) method to determine workload. From the results of the WLA analysis, it was found that the Quality control Tower 1 workload was 119\%, Supervisor Tower 2 was $135 \%$ and Supervisor Tower 3 was $124 \%$ besides that, after calculation the optimal number of employees was obtained by adding 1 labor in Tower 1, Tower 2 and Tower 3.
\end{abstract}

Keywords: Workload Analysis, Work Measurement

\section{Pendahuluan}

Kemampuan bangsa dan rakyat Indonesia dalam pembangunan tidak perlu diragukan mengingat banyaknya candi megah yang tersebar diberbagai wilayah Indonesia. Busro, M, 2018).Menyatakan Hingga saat ini, proyek konstruksi berkembang sejalan dengan perkembangan kehidupan manusia dan kemajuan teknologi. Pastiarsa, M. (2015). Menyatakan Proyek adalah suatu kegiatan yang mempunyai jangka waktu tertentu dengan alokasi sumber daya terbatas untuk melaksanakan suatu tugas yang telah digariskan, atau dalam kata lain proyek merupakan kegiatan

\footnotetext{
*Corresponding author
} 
yang bersifat sementara, tidak berulang, tidak bersifat rutin, mempunyai waktu awal, dan waktu akhir serta sumber daya yang terbatas dalam mencapai sasaran yang telah ditentukan.

Pembuatan rencana suatu proyek konstruksi selalu mengacu pada perkiraan yang ada yakni pada saat rencana pembangunan jadwal tersebut dibuat, masalah dapat timbul apabila ketidaksesuaian antara rencana dengan pelaksanaanya (Hansen, Seng. 2015)., yang mana masalah yang sering terjadi pada pelaksanaan proyek ialah kurangannya sumber daya manusia, sehingga berdampak pada keterlambatan waktu penyelesaian proyek yang disertai dengan meningkatnya biaya pelaksanaan proyek, sama halnya dengan PT Jaya Teknik Indonesia pada proyek Kota Kasablanka 3 yang saat ini mengalami keterlambatan penyelesaian pekerjaan seperti adanya pekerjaan pokok yang tidak sesuai antara job description dengan pekerjaan aktual, penentuan jumlah jumlah tenaga kerja yang tidak seimbang pada Quality Control dan Supervisor dan waktu yang dibutuhkan Quality Control dan Supervisor untuk menyelesaikan tugas-tugasnya.

Berdasarkan review penelitian pertama adalah adalah: Wardah \& Adrian, Jurusan Teknik Industri, Fakultas Teknik dan Ilmu Komputer, Universitas Islam Indragiri, ISSN: 2407-0939, 2017, Judul : "Penentuan Jumlah Karyawan yang Optimal Pada Penanaman Lahan Kelapa Sawit Dengan Menggunakan Metode Work Load Analysis (WLA) PT Bumi Palma Kabupaten Indragiri Hilir Riau". Kesimpulan penelitian : Sebagai perusahaan yang bergerak di sektor perkebunan kelapa sawit di Kabupaten Indragiri Hilir. Perusahaan ini dituntut untuk dapat memenuhi kebutuhan bahan baku kelapa sawit untuk produksi setiap bulannya serta pembukaan dan penggantian lahan yang sudah tidak produktif, Hasil dari penelitian yang dilakukan dengan metode work load analysis (WLA) didapat Beban fisik dari enam orang pekerja yaitu: pekerja 1. Beban kerja sebesar: 113,61\%, pekerja 2 beban kerja sebesar: 121,15\%, Pekerja3. Beban kerja sebesar: 122,17\%, pekerja 4 beban kerja sebesar: 124,06\%, pekerja 5 beban kerja: 101,24\%, pekerja 6 beban kerja sebesar: 74,65\%, disamping itu, setelah dilakukan perhitungan di dapat penambahan sebanyak 2 pekerja sehingga pekerja menjadi 8 orang dengan biaya yang dapat dimaksimalkan jika dilakukan penambahan karyawan 2 orang yaitu sebesar Rp. 83.500,-

Berdasarkan review penelitian kedua adalah: Arsi \& Partiwi, Jurusan Teknik Industri, Fakultas Teknologi Industri, Institut Teknologi Sepuluh Nopember (ITS), ISSN: 2301-9171, 2012, Judul : “Analisis Beban Kerja untuk Menentukan Jumlah Optimal Karyawan dan Pemetaan Kompetensi Karyawan Berdasar Pada Job Description ITS Surabaya", Kesimpulan penelitian : Sebagai salah satu perguruan tinggi terkemuka di Indonesia, juga tidak lepas dari permasalahan beban kerja ini. Adanya empat kali perubahan statuta dan penyesuaian mengenai Organisai Tata Kelola (OTK), membuat pihak ITS harus melakukan reformasi birokrasi dan reformasi organisai untuk mengembangkan ITS kedepannya. Hal ini berdampak pada banyaknya perubahan job description yang dilakukan oleh bidang-bidang yang ada di ITS, termasuk yang menjadi objek penelitian ini yaitu Jurusan Teknik Industri ITS, sehingga beban kerja yang ditanggung oleh setiap karyawan di setiap bidang tidak sesuai dengan jumlah karyawan pada bidang itu sendiri. Oleh karena itu diperlukan suatu analisis pengukuran beban kerja untuk menentukan jumlah optimal karyawan yang seharusnya dibutuhkan oleh setiap bidang. Pada penelitian ini nantinya, yang akan digunakan adalah metode perhitungan beban tugas per jabatan sesuai dengan KEP/75/M.PAN/7/2004 dan NASA-TLX. Kedua metode ini akan digabungkan kedalam suatu perhitungan yang berguna untuk menentukan jumlah optimal karyawan dan didapatkan hasil bahwa terdapat beban kerja yang berlebih pada jabatan sekretaris jurusan, kasubag, juru bayar, juru beli, petugas kepegawaian, dan staff akademik. Selain itu, dalam penelitian ini juga dilakukan pemetaan kompetensi karyawan berdasarkan job description dan dalam pengklasifikasian kompetensinya sesuai dengan jenjang klasifikasi KKNI.

Penelitian ini bertujuan untuk menentukan jumlah kebutuhan tenaga kerja pada suatu aktifitas kerja perusahaan, mengetahui beban kerja yang ada pada tenaga Quality Control dan Supervisor yang ada, dan menentukan waktu yang dibutuhkan Quality Control dan Supervisor untuk menyelesaikan tugas-tugasnya 
Start Of The Art dilakukan dengan mengamati kegiatan tenaga supervisor dan quality control yang terbagi menjadi 2 kegiatan yaitu kegiatan produktif dan tidak produktif. Hal ini bertujuan untuk mengetahui presentase produktifitas masing-masing personil dalam menyelesaikan tugasnya dengan rumus sebagaimana ditunjukkan pada nomor 1 halaman 5 .

Setelah diperoleh hasil presentase produktifnya, selanjutnya uji keseragaman dan uji kecukupan yang sebagaimana ditunjukkan pada nomor 2-4 halaman 5 dan 6 . Uji keseragaman dapat dilakukan untuk mengetahui data yang telah diamati tidak melewati batas kontrol sehingga dapat dikatakan seragam pengujian tersebut dapat diperoleh dengan menggunakan tingkat keyakinan sebesar 95\% dan keteleitian 5\% yang berarti $\mathrm{Z}$ tabelnya 1,96 .

Berdasarkan informasi dari perusahaan, didapatkan data tabel kendala yang ada di Proyek Kota Kasablanka 3:

Tabel 1.Jumlah Pekerjaan Aktual dan Job Description

\begin{tabular}{lccc} 
No & Pekerjaan & Jumlah Pekerjaan \\
\cline { 3 - 4 } & & Aktual & JobDescription \\
\hline 1 & Quality Control Tower 1 & 9 & 6 \\
2 & Supervisor Tower 2 & 9 & 8 \\
3 & Supervisor Tower 3 & 9 & 8 \\
\hline & Jumlah & 27 & \multicolumn{2}{c}{22} \\
\hline Sumber : PT IndoJT & &
\end{tabular}

Berdasarkan tabel 1. diketahui bahwa ada perbedaan jumlah pekerjaan aktual dan pekerjaan yang tertera dalam job description pada tenaga Quality Control dan Supervisor, sehingga kondisi ini dapat dijadikan sebagai dasar untuk menghitung presentase produktivitas dengan menggunakan teknik work sampling dan menganalisis jumlah optimal kebutuhan tenaga Quality Control dan Supervisor di proyek Kota Kasablanka 3 dengan metode workload analysis.

Hasil penelitian dan kontibusi dapat dilihat dalam table 2.berikut ini

$\begin{array}{cccc}\text { No Jabatan Produktif Performance Allowance } & \text { Beban } & \text { Usulan } \\ & & & \text { Kerja } \%\end{array}$

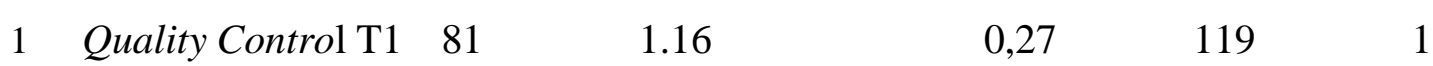

$\begin{array}{llllll}2 & \text { Supervisor T2 } & 88 & 1.18 & 0.30 & 135\end{array}$

1

$\begin{array}{llllll}3 & \text { Supervisor T3 } & 84 & 1.16 & 0.27 & 124\end{array}$

Setelah menentukan jumlah tenaga kerja optimal berdasarkan beban kerja dari ketiga tenaga kerja tersebut. Langkah selanjutnya adaah menentukan waktu baku untuk setiap pekerjaan yang dilakukan denga metode work sampling. Metode ini dipilih karena perhitungan waktu baku dipengaruhi oleh presentase produktif yang telah diperoleh sebelumnya. Selain itu, faktor penyesuaian dan kelonggaran juga akan mempengaruhi 
terhadap waktu yang dihasilkan. Dalam penentuan waktu baku ini, faktor kelonggaran yang digunakan adalah berdasarkan metode Westinghouse Hal ini dikarenakan metode westinghouse berkaitan dengan atau tidak kewajaran kerja dalam bekerja.

Berdasarkan perhitungan waktu baku yang telah dilakukan, tenaga Qualtity control Tower 1 memiliki waktu baku terbesar yaitu selama 17 menit, lalu Supervisor Tower 3 sebesar 16,5 Menit dan Supervisor Tower 2 yaitu sebesar 15,7 menit dalam pekerjaannya. Dari hasil uraian diatas maka dapat dianalisis bahwa dalam penentuan waktu baku untuk menyelesaikan suatu pekerjaan sangat berpengaruh oleh besarnya presentase produktif tenaga kerja itu sendiri dan juga dari banyaknya pekerjaan yang diselesaikan selama pengamatan berlangsung.

\section{Metode Penelitian}

Studi lapangan yang dilakukan adalah observasi atau pengamatan yang dilakukan secara sengaja, sistematis, mengenai aktifitas-aktifitas karyawan untuk kemudian dilakukan pencatatan. Teknik ini dilakukan untuk mengetahui jumlah tenaga kerja dalam keadaan aktual. Dalam pelaksanaannya pengumpulan data terbagi menjadi 2 yaitu data primer dan sekunder Wardah, dkk., 2017).. Data primer merupakan data yang diperoleh dari perusahaan yang terbagi menjadi 2 pengamatan yaitu, kegiatan produktif dan kegaiatan tidak produktif, sedangkan data sekunder ialah data yang berisikan informasi dari teori-teori yang digunakan untuk mendukung penelitian seperti dokumen dan catatan- catatan perusahaan diantaranya, job description dan aktualnya serta data lain yang dibutuhkan dalam penelitian.

Menurut Hermanto (2015) Menyatakan setelah seluruh data yang diperlukan untuk melakukan perhitungan didapatkan, maka dapat dilakukan analisis data yang berhubungan dengan perhitungan, berikut langkah-langkahnya :

\section{(1).Tingkat Produktivitas}

Dimana tingkat produktivitas pekerja didapatkan dengan menggunakan pengukuran kerja yang dilakukan secara langsung untuk mengetahui tingkat produktivitas dan mengetahui data tersebut mencukupi atau valid dengan menggunakan metode sampling kerja.

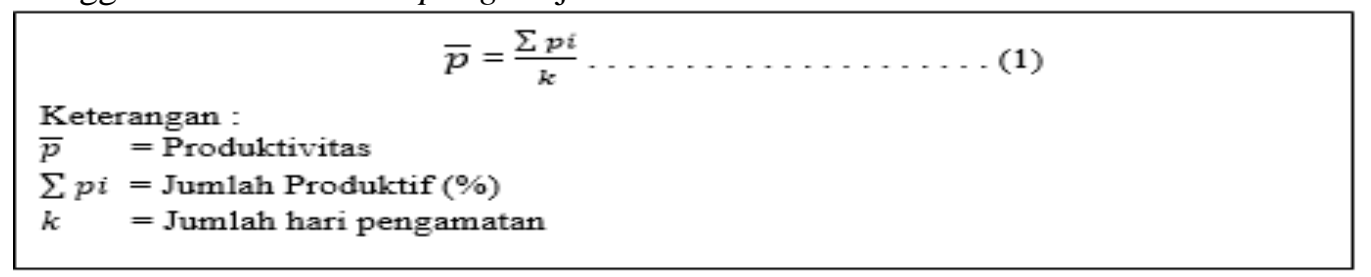

\section{(2). Uji Keseragaman Data}

Dimana tingkat produktivitas pekerja didapatkan dengan menggunakan pengukuran kerja yang dilakukan secara langsung untuk mengetahui tingkat produktivitas dan mengetahui data tersebut mencukupi atau valid dengan menggunakan metode sampling kerja. 
BKA (Batas Kontrol Atas)

$$
\bar{P}+\mathrm{z} \sqrt{\frac{\bar{P}(1-\bar{P})}{n}}
$$

BKB (Batas Kontrol Bawah)

$$
\bar{P}-z \sqrt{\frac{\bar{P}_{(1-\bar{P})}}{\bar{n}}}
$$

Keterangan :

$\bar{P}=$ Jumah data sebenarnya

$Z=$ Nilai acuan yang didapatkan dari tingkat keyakinan dan

Ketelitian

n = Banyaknya frekuensi pengamatan keseluruhan

(3). Uji Kecukupan Data

Uji kecukupan data didapatkan dengan rumus:

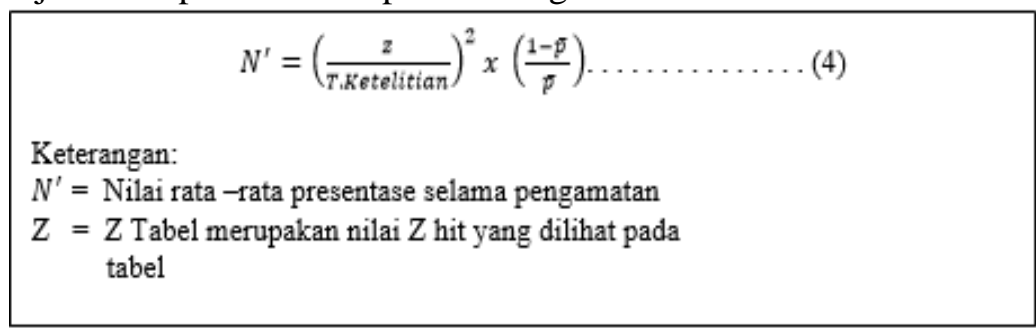

(4).Waktu Baku

a. Waktu Siklus

$$
W s=\frac{\sum x i}{N}
$$

Keterangan:

$\mathrm{Ws}=$ Waktu siklus

$\sum x i=$ Total banyaknya pengamatan

$\mathrm{N}=$ Jumlah pengamatan

b. Waktu Normal

$$
W n=W s \times P
$$

Keterangan:

$\mathrm{Wn}=$ Waktu normal

$\mathrm{Ws}=$ Waktu siklus

$\mathrm{N}=$ Penyesuaian

c.Waktu Baku

\[ W b=W n(1+l) \ldots \ldots \ldots \ldots \ldots(7) \]
Keterangan:
$W b=$ Waktu baku
$\begin{array}{ll}W n=\text { Waktu normal } \\ 1 \quad=\text { Tingkat kelonggaran } \\ l \quad=\text { Kelonggaran yang diberikan }\end{array}$


(5). Beban Kerja

Menurut Rousallen, dkk (2018). Setelah faktor penyesuaian dan kelonggaran yang sudah ditetapkan, maka dapat dihitunglah beban kerja yang diterima oleh pegawai.

Beban kerja $=(\%$ Produktif X Penyesuaian $) \times(1+$ Kelonggaran $) \ldots$. (8)

\section{HASIL DAN PEMBAHASAN}

PT Jaya Teknik Indonesia merupakan perusahaan yang bergerak pada bidang kontraktor mekanikal, elektrikal, elektronik dan teknologi informasi. Penyelesaian dari masalah yang dihadapi PT Jaya Teknik Indonesia yaitu dengan menggunakan Work sampling untuk menentukan produktivitas dan Workload Analysis untuk menentukan beban kerja, Cega, G F, dkk.,2017).

Dalam penelitian ini, peneliti melakukan pengamatan terhadap 1 orang Quality control Tower 1, 1 hari Supervisor Tower 2, dan Supervisor Tower 3 selama 23 hari dari jam $08.30-16.30$ (7 jam), berikut ini adalah hasil pengolahan data:

(1). Menentukan presentase produktif rata - rata pekerja.

Dalam penelitian ini menentukan persentase produktif rata-rata pekerja yaitu dengan mengamati kegiatan non produktif. Didapatkan persentase produktif dengan persentase rata-rata sebesar $67 \%$ dimana perentase tersebut didapatkan dengan rumus:

$$
\bar{p}=\frac{\Sigma p i}{k}=\frac{2024 \%}{23}=88 \%
$$

Dimana nilai tersebut didapatkan dari hasil penelitian yang dilakukan oleh Supervisor Tower 2 yang dilakukan selama 23 hari dengan melakukan pengamatan 3 orang dalam 1 hari.

(2). Uji keseragaman data kegiatan produktif pekerja.

Dengan melakukan pengujian keseragaman data, dimana uji keseragaman untuk mengetahui data yang di amati seragam atau tidak. Dengan menambahkan tingkat keyakinan sebesar $95 \%$, dan tingkat ketelitian $0.05 \%$ juga mencari niai $\mathrm{Z}$ hit didapatkan 0,975 dan $\mathrm{Z}$ table sebesar 1,96 dan didapatkan dari perhitugan pada lampiran diketahui bahwa $\mathrm{BKB}=1.02$ dan $\mathrm{BKA}=0.74$

dengan rumus:

$$
\begin{aligned}
\bar{n} & =\frac{\Sigma n}{k}=\frac{483}{23}=21 \\
\mathrm{BKA} & =\bar{P}+\text { Ztabel } \sqrt{\frac{\bar{P}(1-\bar{P})}{\bar{n}}}=0,88+1,96 \sqrt{\frac{0,88(1-0,88)}{21}}=1,02 \\
\mathrm{BKB} & =\bar{P}-\text { Ztabel } \sqrt{\frac{\overline{\bar{P}(1-\bar{P})}}{\bar{n}}}=0,88-1,96 \sqrt{\frac{0,88(1-0,88)}{21}}=0,74
\end{aligned}
$$


Dan uji keseragaman data kegiatan produktif dapat diihat pada gambar 1.2 grafik keseragaman data.

Gambar 1.Grafik Keseragaman data kegiatan produktif pekerja

Data Keseragaman

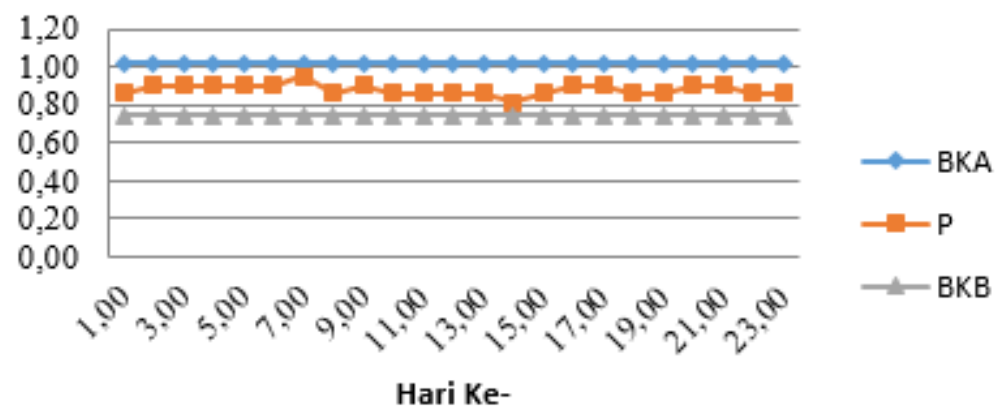

\section{Sumber : Pengolahan data}

Pada gambar 1. Diketahui pada data hasil pengukuran produktivitas pekerja dinyatakan bahwa frekuensi produktivitas tidak melewati batas kontrol atas dan bawah sehingga data tersebut dikatakan seragam.

(3). Uji kecukupan data

Dalam uji kecukupan data dimana data hasil pengamatan yang sudah didapatkan di uji kecukupan datanya untuk mengetahui data tersebut valid atau belum. Uji kecukupan data didapat dengan rumus:

$$
\begin{aligned}
& N^{\prime}=\left(\frac{\text { Zhit }}{\text { T.ketelitian }}\right)^{2} x\left(\frac{1-\bar{p}}{\bar{P}}\right)=\left(\frac{0,97}{0,05}\right)^{2}\left(\frac{1-0,88}{0,88}\right)=210 \\
& \mathrm{P}=425 / 483=0,88 \\
& N=\left(\frac{k}{s}\right)^{2} x\left(\frac{1-P}{P}\right)=\left(\frac{2}{0,05}\right)^{2}\left(\frac{1-0,88}{0,88}\right)=218
\end{aligned}
$$

Dari uji kecukupan data dapat dinyatakan bahwa nilai $\mathrm{N}^{\prime}<\mathrm{N}$. Maka data tersebut sudah mencukupi untuk tingkat keyakinan dan ketelitiannya.

(4). Jumlah pengamatan dan jumlah menit produktif

Jumlah pengamatan yang dilakukan yaitu dengan rumus:

Jumlah pengamatan $=21$ pengamatan $\times 23$ hari $=483$ kali

Jumlah menit pengamatan $=$ Jumlah jam kerja $\times$ jumlah hari pengamatan $=7$ jam $\times 60$ menit $\mathrm{x} 23$ hari $=9660$ menit

Jumlah menit produktif $=$ persentase produktif $\mathrm{x}$ jumlah menit pengamatan $=0,88 \times 9660$ menit $=8500$ menit .

(5). Menghitung Waktu Baku sbb:

\section{Waktu siklus}

Waktu siklus didaa dengan perhitungan sebagai berikut, dengan rumus: 
Waktu siklus $=$ jumlah menit produktif $:$ Barang yang dihasilkan $=8500$ menit $: 832=$ 10,22 menit

\section{Waktu normal}

Waktu normal didapatkan dengan perhitungan sebagai berikut:

Table 3. Hasil Penyesuaian Westinghouse

\begin{tabular}{lcccc}
\hline No Nama & Posisi & \multicolumn{2}{c}{ Faktor Penyesuaian } & Total \\
\cline { 3 - 4 } & & Skill & Effort & Condition Consistency \\
\end{tabular}

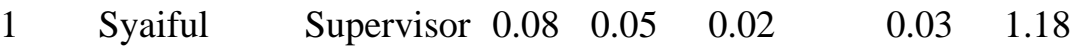

Dari penyesuaian pada tabel 1. Dapat dikethui waktu normal dengan rumus sebagai berikut:

Waktu normal $=$ Waktu siklus $\mathrm{x}$ Penyesuaian $=10,22$ menit $\mathrm{x} 1,18=12,1$ menit

\section{Waktu Baku}

Dimana waktu tersebut didapatkan dari menit produktif di bagi dengan target produksi rata-rata perusahaan atau waktu penyelesaiaan rata-rata selama operator bekerja. Dimana waktu baku didapatkan dari hasil perkalian waktu normal dikalikan kelonggaran. Waktu baku didapatkan dengan perhitungan sebagai berikut, dengan kelonggaran yang didapat sebesar 0,30 dan perhitungannya sebagai berikut dengan rumus:

Waktu Baku $=$ Waktu normalx $(1+$ Kelonggaran $)=12,1$ menit $\mathrm{x}(1+0,30)=12,1$ menit $\mathrm{x}$ $1,30=15,7$ Menit

Tabel 4. Analisis Penentuan Tenaga Kerja

No Jabatan Produktif Performance Allowance Beban kerja Usulan

$\begin{array}{rrrrrrrr}1 & \text { Supervisor T1 } & 81 \% & 1.16 & 0.27 & 119 \% & 1 & \\ 2 & \text { Supervisor T2 } & 88 \% & 1.19 & 0.30 & 135 \% & 1 \\ 3 & \text { Supervisor T3 } & 84 \% & 1.16 & 0.27 & 124 \% & 1 & \end{array}$

Sumber : PT. IndoJT

Berdasarkan dari hasil analisis penentuan tenaga kerja dapat dilihat nilai produktif masing-masing pekerja melebihi dari nilai optimum produktivitas yaitu sebesar $80 \%$ dan masing tenga kerja memiliki masing-masing beban kerja yang dimiliki tenaga kerja melebihi $100 \%$ sehingga usulan penambahan tenaga kerja yang diperlukan masingmasing Tower adalah 1 orang, Presentase kegiatan produktif terbesar dihasilkan oleh Supervisor Tower 2 sebesar yaitu 88\% dengan beban kerja sebesar 135\%, selanjutnya Supervisor Tower 3 presentase produktif sebesar 84\% dengan beban kerja sebesar 124\% lalu Quality Control Tower 1 presentase produktif sebesar $81 \%$ dengan beban kerja sebesar $119 \%$, tenaga Qualtity control Tower 1 memiliki waktu baku terbesar yaitu selama 17 menit, lalu Supervisor Tower 3 sebesar 16,5 Menit dan Supervisor Tower 2 yaitu sebesar 15,7 menit dalam pekerjaannya. 


\section{SIMPULAN}

Berdasarkan dari hasil analisis penentuan tenaga kerja dapat dilihat bahwa masing-masing beban kerja yang dimiliki tenaga kerja melebihi $100 \%$ sehingga usulan penambahan tenaga kerja yang diperlukan masing-masing Tower adalah 1 orang, Presentase kegiatan produktif terbesar dihasilkan oleh Supervisor Tower 2 sebesar yaitu $88 \%$ dengan beban kerja sebesar $135 \%$, selanjutnya Supervisor Tower 3 presentase produktif sebesar $84 \%$ dengan beban kerja sebesar $124 \%$ lalu Quality Control Tower 1 presentase produktif sebesar $81 \%$ dengan beban kerja sebesar 119\%, tenaga Qualtity control Tower 1 memiliki waktu baku terbesar yaitu selama 17 menit, lalu Supervisor Tower 3 sebesar 16,5 Menit dan Supervisor Tower 2 yaitu sebesar 15,7 menit dalam pekerjaannya.

\section{DAFTAR PUSTAKA}

Arsi, P. (2012) Analisis Beban Kerja untuk Menentukan Jumlah Optimal Karyawan dan Pemetaan Kompetensi Karyawan Berdasar Pada Job Description ITS Surabaya. Vol 1,No 1, halaman A526-529

Busro, M. (2018). Teori-teori Manajemen Sumber Daya Manusia. Jakarta: Prenadamedia Group.

Cega, G.F., dkk. (2017). Analisis Beban Kerja dan Kebutuhan Tenaga Kerja Keryawan Divisi Logistik Di PT XYZ Menggunakan Metode Work Sampling. E-Proceeding of Engineering, telkomuniversity.ac.id ,Vol. 4, No.3. halaman 1-8

Hansen, Seng. (2015). Manajemen Kontrak Industri. Jakarta: PT Gramedia Pustaka Utama.

Hermanto. (2013). Analisis Produktivitas Pekerja Di Lantai Produksi Pada PT. Xacti Depok Jawa Barat Dengan Menggunakan Metode Work Sampling. Jurnal Teknik, Vol.3, No.2.

Pastiarsa, M. (2015). Manajemen Kontrak Bangunan Industri; Perspektif Pemilik Proyek. Yogyakarta: Teknosain.

Rousallen, V., dkk. (2018). Analisis Beban Kerja Pegawai di Area Packaging PT. Pudak Scientific. Jurnal Telematika edisi Industrial Engineering Seminar and Call Paper (IESC) 2018 p-ISSN1858-2516 e-ISSN:2579-3772, halaman 37-43

Wardah, S., Adrian, N.I. (2017). Penentuan Jumlah Karyawan yang Optimal Pada Penanaman Lahan Kelapa Sawit Dengan Menggunakan Work Load Analysis (WLA). Jurnal Sains, Teknologi, dan Industri, Vol.3, No.1. halaman 46-52 
[ Halaman Kosong ] 